\title{
Uraemic Pruritus in Dialysis Patient (UP-Dial) questionnaire: creation and validation of the Polish language version
}

\author{
Karolina Świerczyńska1, Piotr Krajewski ${ }^{1}$, Radomir Reszke ${ }^{1}$, Magdalena Krajewska², Surapon Nochaiwong ${ }^{3}$, \\ Rafał Biatynicki-Birula ${ }^{1}$, Jacek C. Szepietowski ${ }^{1}$
}

${ }^{1}$ Department of Dermatology, Venereology and Allergology, Wroclaw Medical University, Wroclaw, Poland ${ }^{2}$ Department of Nephrology and Transplantation Medicine, Wroclaw Medical University, Wroclaw, Poland ${ }^{3}$ Department of Pharmaceutical Care; Pharmacoepidemiology and Statistics Research Center (PESRC), Faculty of Pharmacy, Chiang Mai University, Chiang Mai, Thailand

Adv Dermatol Allergol 2022; XXXIX (3): 538-544 DOI: https://doi.org/10.5114/ada.2021.107271

\begin{abstract}
Introduction: Uraemic pruritus is a common and burdensome symptom in patients undergoing haemodialysis. Though a significant negative impact of chronic itch on patient's quality of life is proved, this problem is still often underestimated in clinical practice. Various instruments describing itch are in use, however only recently a specific instrument for uraemic itch - Uraemic Pruritus in Dialysis Patient (UP-Dial) - questionnaire has been created.

Aim: To translate and to validate the Polish version of the UP-Dial questionnaire.

Material and methods: Forward and backward translations were conducted according to international standards. The validation was performed on a group of 30 patients undergoing haemodialysis and suffering from uraemic itch. Respondents completed the questionnaire twice with a 3-7 days' interval. Moreover, for convergent validity, the subjects were asked to assess their itch with the Numerical Rating Scale (NRS), 4-Item Itch Questionnaire (4IIQ) as well as ItchyQoL questionnaire.

Results: The Polish version of the UP-Dial questionnaire showed very good internal consistency - Cronbach $\alpha$ coefficient was 0.90 for total score. The reproducibility assessed with the intraclass correlation coefficient (ICC) was also very good -0.9 . Furthermore, UP-Dial correlated strongly with NRS $(r=0.74, p<0.01), 4 I \mathrm{Q}(r=0.82, p<0.01)$ and ItchyQoL $(r=0.88, p<0.01)$.

Conclusions: The Polish version of the UP-Dial questionnaire showed high internal reliability, validity and reproducibility and can be widely used both in research and in daily clinical practice.
\end{abstract}

Key words: pruritus, questionnaire, haemodialysis, quality of life, validation.

\section{Introduction}

Chronic kidney disease-associated pruritus (CKDaP), which for years has been known as uraemic pruritus (UP), is a common and burdensome symptom in patients undergoing dialysis. This condition was first described by Chargin and Keil in 1932 [1]. Despite the long-standing studies in this area, the complex etiopathogenesis of UP is still not fully understood. According to studies published so far, the current prevalence of UP is about $40 \%$ [2-5]. UP has a confirmed negative impact on the patient's sleep, daily activities and quality of life $(\mathrm{Q} o \mathrm{~L})$, while it is also responsible for mood disturbances, depression and increased mortality risk [5-8]. Despite many years of trials, therapy of UP is still a challenge for nephrologists and dermatologists.

In clinical practice various instruments have been used to evaluate chronic pruritus. Due to the multifactorial and subjective nature, the International Forum for the Study of Itch (IFSI) recommended an extensive evaluation of chronic pruritus including its intensity, clinical course and consequences [9]. Although several instruments, including the Numerical Rating Scale (NRS), Visual Analogue Scale (VAS), 4-Item Itch Questionnaire (4IIQ),

Address for correspondence: Prof. Jacek C. Szepietowski, Department of Dermatology, Venereology and Allergology, Wroclaw Medical University, Wroclaw, Poland, phone: +48 601534853, e-mail: jacek.szepietowski@umed.wroc.pl Received: 31.03.2021, accepted: 25.04.2021. 
5D-Itch Scale, ItchyQoL are available, there has been no specific questionnaire designed to characterize UP in dialysis patients. In 2016, Nochaiwong et al. [10] developed a standardized multidimensional 14-item instrument - Uraemic Pruritus in Dialysis Patients (UP-Dial). It evaluates three dimensions of UP in patients on dialysis: signs and symptoms, sleep and psychosocial burden during the last 2 weeks [10].

\section{Aim}

The aim of this study was to translate and to validate the Polish version of the UP-Dial questionnaire to enable its use by Polish speaking patients.

\section{Material and methods}

The Polish version of the UP-Dial questionnaire was translated and validated according to the international standards. The permission to translate the questionnaire was provided by the copyright holders. The research obtained ethical approval by the Wroclaw Medical University Ethics Committee (Consent no. 26/2021).

\section{Translations and validation}

Firstly, the original English version of the UP-Dial questionnaire was translated into the Polish language by two independent translators. Then the translated versions were compared in terms of discrepancies by a third counsellor who is a bilingual expert in the field. The unified version was created. Subsequently, another two independent translators, who were not familiar with the original version of the UP-Dial questionnaire, did the back-translation from Polish to English. Afterwards, the back translations were sent to the members of the team who created the original questionnaire. All raised comments were carefully considered. Finally, the Polish version of the instrument was invented.

After the translation process, the preliminary validation was performed. The questionnaire was completed by a group of 30 patients on maintenance haemodialysis. All of them were suffering from UP. The group consisted of 17 men and 13 women aged 22-83 years (mean age: $63.3 \pm 14.3$ years). The average duration of haemodialysis was 52.5 \pm 40.5 months (range: 5 weeks -144 months). The patients presented the following aetiology of end stage renal disease: nephrosclerosis (36.7\%), diabetes mellitus (30\%), polycystic kidney disease (10\%) and other causes that occurred only in single cases. The responders were asked to complete the questionnaire twice with an interval of 3-7 days. This period was considered long enough to prevent the patients from remembering previous answers, as well as short enough to prevent any noticeable changes in the characteristics of pruritus. Assessments were supervised by one of the authors of the Polish version of UP-Dial, who controlled the time required to complete the survey. The participants of the study had the opportunity to report any concerns related to the questionnaire. For convergent validity patients were also asked to assess their pruritus with NRS (worst itch intensity during the last 3 days) [11] and 4-Item Itch Questionnaire [12]. Additionally, they filled the Polish version of ItchyQoL [13].

NRS is an easily accessible instrument commonly used to evaluate the intensity of pruritus. On a scale from 0 to 10 points, results over 7 points indicate severe itch [14]. 4IIQ consists of 4 questions which characterize different aspects of itch. First question applies to the extensity of itch, second - to intensity, third - to frequency and fourth - to sleep disturbances caused by itch. The possible score by patients, who experience itch, ranges from 3 to 19 points [12]. ItchyQoL is a validated 22-question instrument, consisting of three dimensions: symptoms, functional limitations and emotions, which estimates influence of chronic itch on QoL [15]. Questions are scored on a 5 -point scale (1 - never; 2 - rarely; 3 - sometimes; 4 - often; 5 - all of the time), with the sum forming the total ItchyQoL score with a range of 22-110 [16].

\section{Statistical analysis}

All data analyses were carried out using Statistica 13 software (Dell, Inc., Tulsa, USA).

The internal consistency of the instrument was evaluated with Cronbach $\alpha$ coefficient. To establish that the questionnaire is internally consistent, the Cronbach coefficient should reach at least 0.70 , while the value above 0.90 indicates very good internal consistency [17].

The questionnaire reproducibility (test-retest reliability) was assessed by using intraclass correlation coefficient (ICC), with results $\geq 0.70$ indicating adequate reproducibility [18].

Additionally, responses to each question from the first and the second completion were compared using Wilcoxon test. The correlation between answers from a single completion to each individual question and to the total score was established with Spearman correlation test. Convergent validity was based on the Spearman rank correlation test between UP-Dial and other instruments (NRS, 4IIQ and ItchyQoL). P-values less than 0.05 were considered as statistically significant.

\section{Results}

Cronbach $\alpha$ coefficient value of UP-Dial total score was 0.90 , which indicated very good internal consistency of the validated instrument. Furthermore, each of the three domains presented good or very good internal consistency with Cronbach $\alpha$ coefficient of 0.75 for the signs and symptoms domain, 0.93 for the sleep domain and 0.75 for the psychosocial domain.

Significant correlations between most of the results obtained for each item and the total score of the translated questionnaire were found. Only questions 5, 7 and 14 did not correlate with the total score (Table 1). 
Table 1. The correlation coefficients between the answers to each question and between the answers to each question and the total score of the UP-Dial questionnaire

\begin{tabular}{|c|c|c|c|c|c|c|c|c|c|c|c|c|c|c|}
\hline Item & Q1 & Q2 & Q3 & Q4 & Q5 & Q6 & Q7 & Q8 & Q9 & Q10 & Q11 & Q12 & Q13 & Q14 \\
\hline Q1 & 1 & & & & & & & & & & & & & \\
\hline Q2 & $0.614^{b}$ & 1 & & & & & & & & & & & & \\
\hline Q3 & $0.668^{b}$ & $0.668^{b}$ & 1 & & & & & & & & & & & \\
\hline Q4 & $0.526^{b}$ & $0.545^{b}$ & $0.588^{b}$ & 1 & & & & & & & & & & \\
\hline Q5 & $0.236^{c}$ & $-0.031^{c}$ & $0.228^{c}$ & $0.266^{c}$ & 1 & & & & & & & & & \\
\hline Q6 & $0.146^{c}$ & $0.184^{c}$ & $0.085^{c}$ & $0.250^{c}$ & $0.436^{a}$ & 1 & & & & & & & & \\
\hline Q7 & $0.362^{\mathrm{a}}$ & $0.175^{c}$ & $0.118^{c}$ & $-0.011^{c}$ & $0.098^{c}$ & $0.116^{c}$ & 1 & & & & & & & \\
\hline Q8 & $0.707^{b}$ & $0.609^{b}$ & $0.589^{b}$ & $0.532^{b}$ & $0.117^{c}$ & $0.082^{c}$ & $0.031^{c}$ & 1 & & & & & & \\
\hline Q9 & $0.702^{b}$ & $0.464^{b}$ & $0.518^{b}$ & $0.577^{b}$ & $0.293^{c}$ & $0.408 a$ & $0.107^{c}$ & $0.621^{b}$ & 1 & & & & & \\
\hline Q10 & $0.609^{b}$ & $0.495^{b}$ & $0.393^{\mathrm{a}}$ & $0.459^{a}$ & $0.254^{c}$ & $0.317^{c}$ & $0.207^{c}$ & $0.736^{\mathrm{b}}$ & $0.730^{b}$ & 1 & & & & \\
\hline Q11 & $0.682^{b}$ & $0.610^{\mathrm{b}}$ & $0.731^{b}$ & $0.652^{b}$ & $0.368 a$ & $0.413^{a}$ & $0.162^{c}$ & $0.477^{b}$ & $0.747^{b}$ & $0.535^{b}$ & 1 & & & \\
\hline Q12 & $0.566^{b}$ & $0.372^{\mathrm{a}}$ & $0.432 a$ & $0.518^{b}$ & $0.412^{\mathrm{a}}$ & $0.513^{b}$ & $0.094^{c}$ & $0.519^{b}$ & $0.687^{b}$ & $0.650^{\mathrm{b}}$ & $0.613^{b}$ & 1 & & \\
\hline Q13 & $0.506^{\mathrm{b}}$ & $0.601^{b}$ & $0.627^{b}$ & $0.248^{c}$ & $0.194^{c}$ & $0.356^{c}$ & $0.107^{c}$ & $0.536^{b}$ & $0.502^{b}$ & $0.534^{b}$ & $0.650^{b}$ & $0.412^{a}$ & 1 & \\
\hline Q14 & $0.071^{c}$ & $0.035^{c}$ & $0.384^{a}$ & $0.003^{c}$ & $0.178^{c}$ & $0.087^{c}$ & $-0.059^{c}$ & $0.100^{c}$ & $0.007^{c}$ & $0.016^{\mathrm{b}}$ & $0.043^{c}$ & $0.170^{c}$ & $0.211^{c}$ & 1 \\
\hline Total & $0.823^{b}$ & $0.757^{b}$ & $0.726^{b}$ & $0.629^{b}$ & $0.342^{c}$ & $0.457^{a}$ & $0.333^{c}$ & $0.758^{b}$ & $0.735^{b}$ & $0.754^{b}$ & $0.775^{b}$ & $0.665^{b}$ & $0.716^{b}$ & $0.145^{c}$ \\
\hline
\end{tabular}

${ }^{a} p<0.05 ; b<<0.01 ; c^{c}>0.05 ; Q$ - question.

The ICC used for the evaluation of the questionnaire reproducibility was very high -0.90 . Moreover, besides only two questions (1 and 2), no statistically significant differences were found for each particular question answered during the first and the second completion (Table 2). Both questions mentioned above belong to the signs and symptoms domain, which also significantly differed between the assessments. A strong positive correlation $(r=0.93, p<0.001)$ was found between the results of the total score from both assessments. Likewise, positive correlations were also found for each particular question (detailed data not shown).

Two of the instruments used for the evaluation of convergent validity in the study assessed the severity of the itch. The score of the worst itch intensity during the last 3 days, estimated by NRS, ranged between 1 and 8 points with the mean of $4.8 \pm 2.0$ points. The results of $4 \mathrm{IIQ}$ were in the range from 4 to 18 points. The mean result was $9.2 \pm 4$. 1 points. The evaluation of convergent validity showed a strong correlation between UP-Dial and the instruments which assess intensity of the itch - NRS $(r=0.74, p<0.01)$ and $4 \| \mathrm{Q}(r=0.82, p<0.01)$. Similarly, the UP-Dial questionnaire strongly correlated with ItchyQoL $(r=0.88, p<0.01)$ (Figure 1). Additionally, each domain of the survey showed a significant correlation with all the above-mentioned instruments (Table 3).

The results presented in our study proved very good internal consistency, reproducibility and convergent validity of the Polish version of the UP-Dial questionnaire. The respondents reported good comprehensibility of the questions and the process of completing the whole in- strument took 7-10 min. None of patients reported any difficulties in understanding the questionnaire items. The Polish validated version of UP-Dial is presented in Appendix 1.

\section{Discussion}

UP is one of the most common dermatological symptoms associated with chronic kidney disease [19]. Despite the evolution of dialysis methods during past decades, this problem still bothers about $40 \%$ of patients undergoing haemodialysis $[5,20]$. The characteristics of UP include intensity, localization and consequences of the itch differ among patients. Nevertheless, a significant negative impact of chronic itch on patients' quality of life has been proved, yet this problem is still often underestimated in clinical practice [21]. In order to characterize UP, a multidimensional instrument is necessary. Although various instruments describing itch are in use, so far there has been no specific tool designed particularly for itch in dialysis patients. UP-Dial seems to be the first instrument ever developed specifically for UP. This questionnaire contains three domains: signs and symptoms, sleep and psychosocial. These domains investigate all important aspects of chronic itch: frequency, intensity, distribution, skin lesions caused by itch, impact on sleep and psychosocial life of the patient. The total score of UP-Dial also enables classifying the severity of itch. Moreover, Nochaiwong et al. [22] proposed cut-off points of this instrument, which present as follows: $\leq 12$ points indicate mild, 13-21 points moderate and $\geq 22$ points severe itch. 
Table 2. Reproducibility of results

\begin{tabular}{|c|c|c|c|c|c|c|c|}
\hline \multirow[t]{2}{*}{ Item } & \multicolumn{3}{|c|}{$1^{\text {st }}$ assessment [points] } & \multicolumn{3}{|c|}{$2^{\text {st }}$ assessment [points] } & \multirow[t]{2}{*}{$P$-value } \\
\hline & Median & $1^{\text {st }}$ quartile & $3^{\text {rd }}$ quartile & Median & $1^{\text {st }}$ quartile & $3^{\text {rd }}$ quartile & \\
\hline Q1 & 0.00 & 0.00 & 2.00 & 0.00 & 0.00 & 1.00 & 0.021 \\
\hline Q2 & 2.00 & 2.00 & 2.00 & 2.00 & 1.00 & 2.00 & 0.034 \\
\hline Q3 & 1.50 & 1.00 & 2.00 & 1.00 & 1.00 & 2.00 & 0.726 \\
\hline Q4 & 1.00 & 0.00 & 2.00 & 1.00 & 1.00 & 2.00 & 0.469 \\
\hline Q5 & 0.00 & 0.00 & 0.00 & 0.00 & 0.00 & 0.00 & 0.063 \\
\hline Q6 & 0.00 & 0.00 & 1.00 & 0.00 & 0.00 & 1.00 & 0.206 \\
\hline Q7 & 4.00 & 3.00 & 4.00 & 4.00 & 3.00 & 4.00 & 0.942 \\
\hline Q8 & 1.00 & 0.00 & 4.00 & 0.50 & 0.00 & 2.00 & 0.527 \\
\hline Q9 & 0.00 & 0.00 & 1.00 & 0.00 & 0.00 & 1.00 & 1 \\
\hline Q10 & 0.00 & 0.00 & 1.00 & 0.00 & 0.00 & 2.00 & 0.527 \\
\hline Q11 & 0.00 & 0.00 & 2.00 & 0.00 & 0.00 & 2.00 & 0.102 \\
\hline Q12 & 0.00 & 0.00 & 1.00 & 0.00 & 0.00 & 0.00 & 0.317 \\
\hline Q13 & 1.00 & 0.00 & 2.00 & 1.00 & 0.00 & 2.00 & 0.813 \\
\hline Q14 & 0.00 & 0.00 & 0.00 & 0.00 & 0.00 & 0.00 & 0.317 \\
\hline Signs and symptoms & 9.00 & 7.00 & 14.00 & 8.00 & 6.00 & 13.00 & 0.025 \\
\hline Sleep & 1.00 & 0.00 & 4.00 & 1.00 & 0.00 & 5.00 & 0.783 \\
\hline Psychosocial & 2.00 & 0.00 & 4.00 & 1.50 & 0.00 & 4.00 & 0.248 \\
\hline Total score & 11.00 & 8.00 & 21.00 & 10.50 & 8.00 & 21.00 & 0.064 \\
\hline
\end{tabular}

O-question.

\section{A}

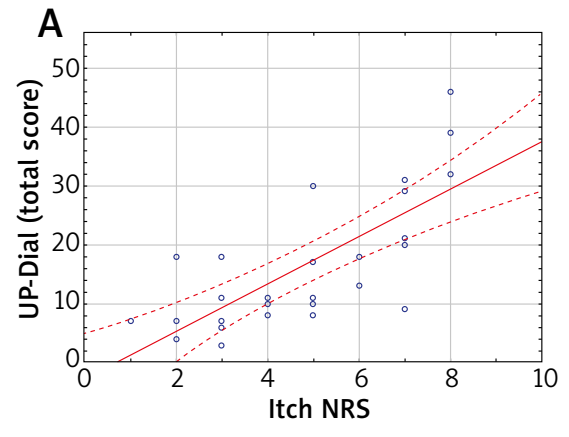

$p<0.001, r=0.737$

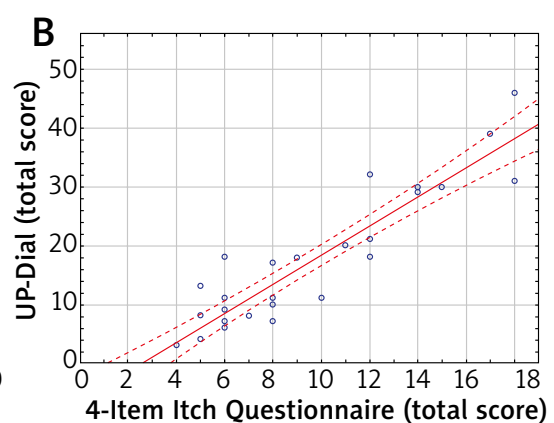

$p<0.001, r=0.823$

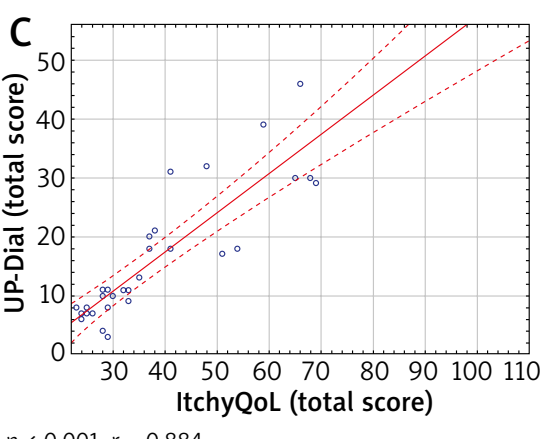

$p<0.001, r=0.884$

Figure 1. The correlations between UP-Dial and Itch NRS (A), 4-Item Itch Questionnaire (B) and ItchyQoL (C)

This study describes the process of development and validation of the Polish language version of the UP-Dial questionnaire. The translated Polish version showed very good internal consistency with Cronbach $\alpha$ value of 0.90 for the total score and $0.75-0.93$ for the three domains. These results are similar to those obtained by the authors of the original version of the questionnaire (Cronbach $\alpha 0.90$ for total score, for domains: $0.76-0.83$ ). To the best of our knowledge, only the Chinese version of UP-Dial has been validated up till now. Li et al. [23], similarly to us proved a good internal consistency of the instrument with Cronbach $\alpha$ coefficient value of $0.75,0.71$, 0.85 of the three subscales (signs and symptoms, sleep and psychosocial) and 0.89 of the whole scale. Three
Table 3. Correlation coefficients between each domain of UP-Dial and other instruments

\begin{tabular}{llll}
\hline & Signs and symptoms & Sleep & Psychosocial \\
\hline NRS & 0.705 & 0.608 & 0.652 \\
\hline 4IIQ & 0.831 & 0.738 & 0.684 \\
\hline ItchyQoL & 0.765 & 0.806 & 0.880 \\
\hline
\end{tabular}

NRS - Numerical Rating Scale, 4IIQ - 4-Item Itch Questionnaire.

items of UP-Dial did not show correlation with the total score. Responses to questions 5, 7 and 14 showed a lack of variety. Despite significant diversity of final assessment of the itch, the vast majority of the respondents 
did not report numbness (question 5) and confirmed constant dryness of the skin (question 7).

Similarly, almost every patient denied any sexual difficulties caused by pruritus (question 14). This may be a result of intimate nature of the question and perceiving sexuality as taboo.

In our study very good reproducibility was achieved with the value of ICC of 0.90 for the whole survey, which was close to the original version $(I C C=0.95)$. Two questions ( 1 and 2 ) and the signs and symptoms domain differed between both measurements, most likely due to subjective perception and variability of the itch.

The evaluation of convergent validity showed a strong correlation between UP-Dial and the other instruments employed for this purpose. The authors of the original paper, similarly to our analysis, proved that UPDial is strongly related to other tools. Nochaiwong et al. [10] used, for convergent validity procedure, the Visual Analogue Scale $(r=0.76, p<0.001)$ which as well as NRS, applied in our study, describes intensity of the itch. At the time of creation of the original version, ItchyQoL - the tool which estimates influence of chronic itch on QoL, has not been used widely. Therefore, to assess convergent validity of UP-Dial in terms of patients' quality of life the authors employed the Dermatology Life Quality Index $(r=0.78, p<0.001)[10]$.

We are aware of some limitations of our study. This research was a one centre study. Moreover, the preliminary validation was performed on a limited number of patients suffering from UP. Future studies will be helpful to confirm our current findings.

Having a Polish language version of this multidimensional instrument will enable its use in daily clinical practice to characterize UP in Polish speaking patients on maintenance dialysis and can be of help in evaluation of the effects of applied itch therapy. Creation and validation of new language versions of this questionnaire may help in the future to better understand the issue of uraemic pruritus in dialysis patients in different populations.

\section{Conflict of interest}

The authors declare no conflict of interest.

\section{References}

1. Chargin L, Keil H. Skin diseases in nonsurgical renal disease. AMA Arch Derm 1932; 26: 314-35.

2. Weisshaar E. Epidemiology of uraemic itch: new data. Eur J Pain 2016; 20: 32-6.

3. Szepietowski JC, Sikora M, Kusztal M, et al. Uremic pruritus: a clinical study of maintenance hemodialysis patients. J Dermatol 2002; 29: 621-7.

4. Heisig M, Reich A, Szepietowski JC. Is uremic pruritus still an important clinical problem in maintenance hemodialysis patients? J Eur Acad Dermatol Venereol 2016; 30: e198-9.

5. Pisoni RL, Wikström B, Elder SJ, et al. Pruritus in haemodialysis patients: International results from the Dialysis Out- comes and Practice Patterns Study (DOPPS). Nephrol Dial Transplant 2006; 21: 3495-505.

6. Mollanazar NK, Koch SD, Yosipovitch G. Epidemiology of chronic pruritus: where have we been and where are we going? Curr Derm Rep 2015; 4: 20-9.

7. Suseł J, Batycka-Baran A, Reich A, Szepietowski JC. Uraemic pruritus markedly affects the quality of life and depressive symptoms in haemodialysis patients with end-stage renal disease. Acta Derm Venereol 2014; 94: 276-81.

8. Mathur VS, Lindberg J, Germain M, et al. A longitudinal study of uremic pruritus in hemodialysis patients. Clin J Am Soc Nephrol 2010; 5: 1410-9.

9. Ständer S, Augustin M, Reich A, et al. Pruritus assessment in clinical trials: consensus recommendations from the International Forum for the Study of Itch (IFSI) Special Interest Group Scoring Itch in Clinical Trials. Acta Derm Venereol 2013; 93: 509-14.

10. Nochaiwong S, Ruengorn C, Awiphan R, et al. Development of a multidimensional assessment tool for uraemic pruritus: Uraemic Pruritus in Dialysis Patients (UP-Dial). Br J Dermatol 2017; 176: 1516-24.

11. Phan NQ, Blome C, Fritz F, et al. Assessment of pruritus intensity: prospective study on validity and reliability of the visual analogue scale, numerical rating scale and verbal rating scale in 471 patients with chronic pruritus. Acta Derm Venereol 2012; 92: 502-7.

12. Reich A, Mędrek K, Szepietowski J. Four-item itch questionnaire - validation of questionnaire. Dermatol Rev 2012; 99 : 600-4.

13. Zeidler C, Steinke S, Riepe C, et al. Cross-European validation of the ItchyQoL in pruritic dermatoses. J Eur Acad Dermatol Venereol 2019; 33: 391-7.

14. Reich A, Chatzigeorkidis E, Zeidler C, et al. Tailoring the cut-off values of the visual analogue scale and numeric rating scale in itch assessment. Acta Derm Venereol 2017; 97: 759-60.

15. Desai NS, Poindexter GB, Monthrope YM, et al. A pilot quality-of-life instrument for pruritis. J Am Acad Dermatol 2008; 59: 234-44.

16. Love EM, Marrazzo GA, Kini S, et al. ItchyQoL bands: pilot clinical interpretation of scores. Acta Derm Venereol 2015; 95: 114-5.

17. Cronbach LJ. Coefficient alpha and the internal structure of tests. Psychometrika 1951; 16: 297-334.

18. Shrout PE, Fleiss JL. Intraclass correlations: uses in assessing rater reliability. Psychol Bull 1979; 86: 420-8.

19. Galperin TA, Cronin AJ, Leslie KS. Cutaneous manifestations of ESRD. Clin J Am Soc Nephrol 2014; 9: 201-18.

20. Patel TS, Freedman BI, Yosipovitch G. An update on pruritus associated with CKD. Am J Kidney Dis 2007; 50: 11-20.

21. Szepietowski JC, Balaskas E, Taube KM, et al. Quality of life in patients with uraemic xerosis and pruritus. Acta Derm Venereol 2011; 91: 313-7.

22. Nochaiwong S, Ruengorn C, Koyratkoson K, et al. Clinical interpretation of the Uremic Pruritus in Dialysis Patients (UP-Dial) scale: a novel instrument for the assessment of uremic pruritus. J Eur Acad Dermatol Venereol 2018; 32: 1188-94.

23. Li J, Chen FL, Zhao XR, et al. The reliability and validity of the 14-item uremic pruritus in dialysis patients scale (Chinese version scale). Chin J Blood Purif 2019; 18: 575-8. 


\section{Appendix}

\section{4-punktowa skala świądu mocznicowego u chorych dializowanych}

1. W ciągu ostatnich 2 tygodni ile godzin średnio w ciągu danej doby odczuwał (odczuwała) Pan (Pani) świąd?

$\square$ Mniej niż 6 godzin na dobę [0]

$\square$ 6-12 godzin na dobę [1]

$\square$ 12-18 godzin na dobę [2]

$\square$ 18-23 godzin na dobę [3]

$\square$ Całą dobę [4]

2. W okresie ostatnich 2 tygodni, jak bardzo nasilony był świąd, jaki Pan (Pani) odczuwał (odczuwała)?

$\square$ Nie odczuwałem (nie odczuwałam) świądu [0]

$\square$ Łagodny [1]

$\square$ Umiarkowany [2]

$\square$ Ciężki [3]

$\square$ Nie do zniesienia [4]

3. W ciągu ostatnich 2 tygodni, których okolic ciała dotyczył świąd? Proszę zacieniować te obszary.
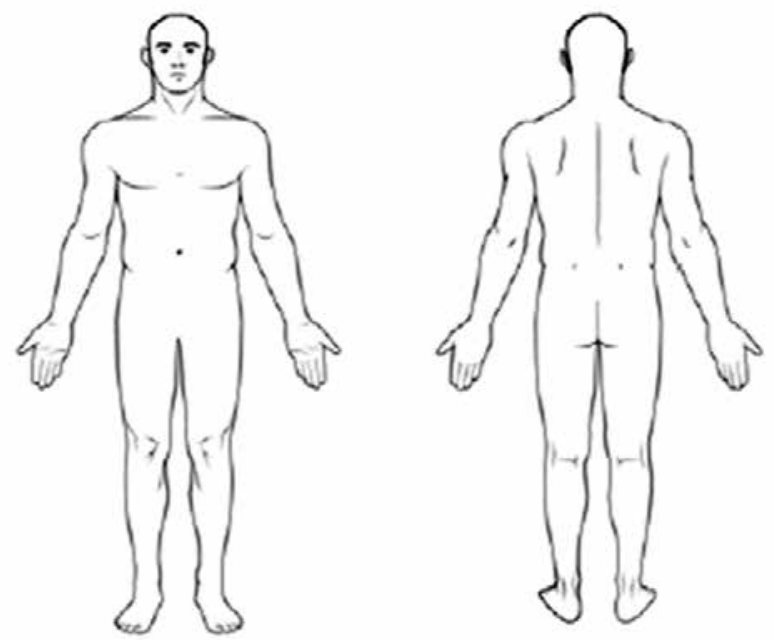

0\% powierzchni ciała [0]

$1-25 \%$ powierzchni ciała [1]

26-50\% powierzchni ciała [2]

$\square$ 51-75\% powierzchni ciała [3]

$\square$ 76-100\% powierzchni ciała [4] 
Proszę ocenić częstość występowania poniższych objawów związanych ze świądem w okresie ostatnich 2 tygodni.

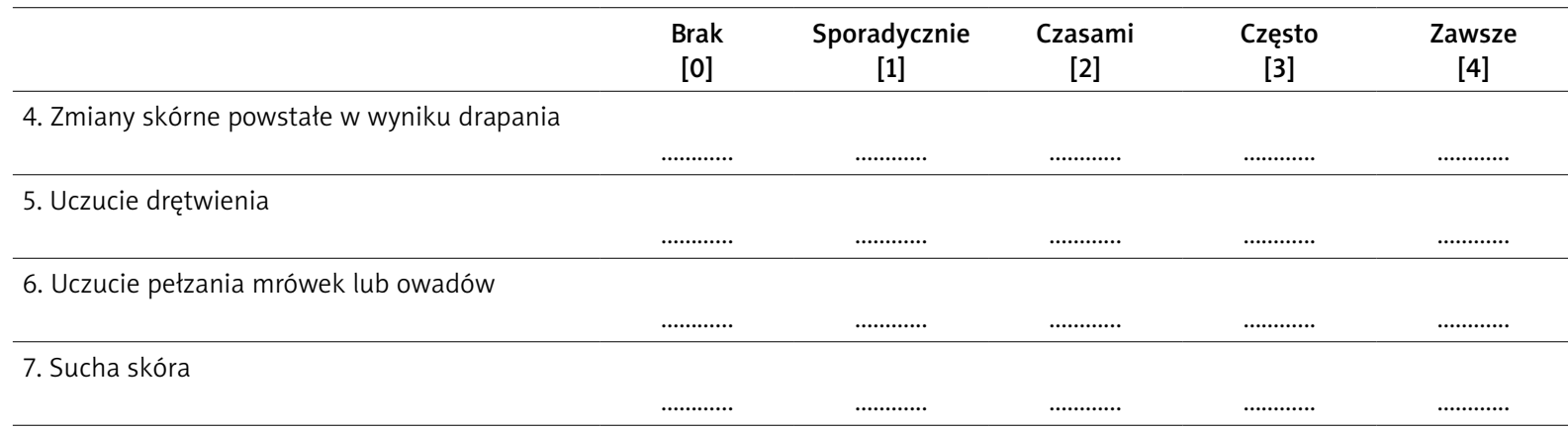

Jak często świąd zakłócał Pana (Pani) sen?

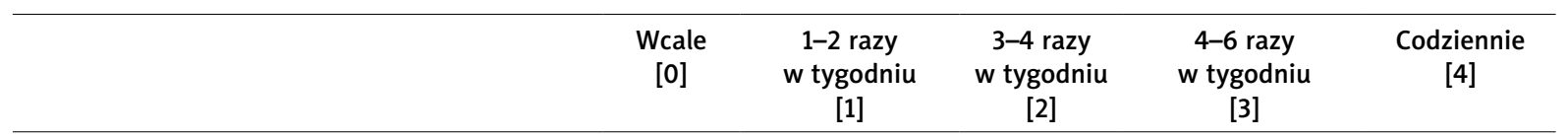

8. Trudności z zasypianiem (więcej niż 30 minut)

\begin{tabular}{|c|c|c|c|c|c|}
\hline & $\ldots \ldots \ldots \ldots$ & 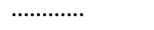 & .................... & …................ & $\ldots \ldots \ldots \ldots$ \\
\hline \multicolumn{6}{|l|}{ 9. Budzenie się w nocy } \\
\hline & .............. & ............... & ............... & ............... & ............... \\
\hline \multicolumn{6}{|l|}{ 10. Zakłócenie jakości snu } \\
\hline & .............. & .............. & ............... & .............. & .............. \\
\hline \multicolumn{6}{|c|}{ Proszę ocenić wpływ świądu na następujące aktywności lub domeny w ciągu ostatnich 2 tygodni. } \\
\hline & $\begin{array}{c}\text { Brak } \\
{[0]}\end{array}$ & $\begin{array}{c}\text { Łagodny } \\
{[1]}\end{array}$ & $\begin{array}{c}\text { Umiarkowany } \\
{[2]}\end{array}$ & $\begin{array}{l}\text { Silny } \\
\text { [3] }\end{array}$ & $\begin{array}{c}\text { Bardzo silny } \\
\text { [4] }\end{array}$ \\
\hline
\end{tabular}

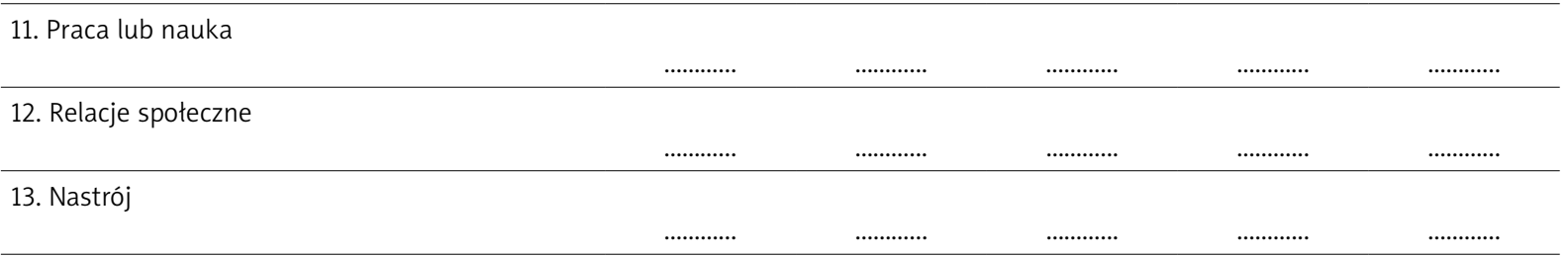

14. Wszelkie problemy seksualne

\begin{tabular}{|c|c|c|}
\hline …….. & $\cdots$. & \\
\hline
\end{tabular}

